\title{
Тумесцентна анестезія як різновид місцевої анестезії в акушерстві при виконанні неакушерсыких операцій під час вагітності
}

\author{
V. M. ANTONYUK-KYSIL, V. M. YENIKEYEVA, S. I. LICHNER, V. M. LYPNYI, V. V. DROZD \\ Municipal Institution "Regional Perinatal Centre" of Rivne Regional Council
}

\section{TUMESCENT ANAESTHESIA AS A VARIETY OF LOCAL ANAESTHESIA IN OBSTETRICS IN THE COURSE OF NON-OBSTETRICAL SURGERY DURING PREGNANCY}

\begin{abstract}
У статті дано оцінку тумесцентній анестезії (різновиду місцевої анестезії), яка дала можливість безпечного виконання хірургічного втручання на підшкірних венах нижніх кінцівок і промежини під час вагітності, з метою запобігання прогресуванню варикозної хвороби нижніх кінцівок, статевих губ і промежини у вагітних у II або в III триместрі вагітності. Хірургічне лікування проведено 114 вагітним. Виконано 154 операційні втручання. Використали для знеболювання у 90,8 \% прооперованих вагітних тумесцентну анестезію. Впливу на перебіг вагітності, пологів, на плід не виявлено.

The article is an assessment of tumescent anesthesia (kind of local anesthesia) which made it possible to safely perform surgery on saphenous veins of the lower extremities and perineum during pregnancy, with the aim of preventing the progression of varicose veins of the lower extremities, labia and perineum in pregnant women in II or III trimester of pregnancy. Surgical treatment was carried out for 114 pregnant women. 154 surgeries were performed. Tumescent anesthesia was used for pain relief in $\mathbf{9 0 . 8 \%}$ of postoperative pregnant women. The effects on pregnancy, childbirth, the fetus were not found.
\end{abstract}

Постановка проблеми і аналіз останніх досліджень та публікацій. У наші дні для варикозної хвороби нижніх кінцівок, особливо в жінок, характерний тільки ріст кількості захворювань 3 тенденцією до прогресування в осіб активного репродуктивного віку. Варикозне розширення підшкірних вен нижніх кінцівок і зовнішніх статевих органів, за даними різних авторів, спостерігається у від 2 до 50 \% вагітних. Більше як у половини вагітних (60-80 \%) захворювання виникає під час вагітності і складає 5,6 \% із всієї екстрагенітальної патології при вагітності [24, 33, 39].

На думку В. А. Ніколаєнкової (1970) [20], варикоз, що виник під час вагітності, не зникає, а прогресує під час наступної вагітності. Встановлено, що у 20 \% вагітних вульварний варикоз збільшується і зберігається з часом у віддаленому періоді [32, 37]. За даними В. В. Петрова, які він надав у 2011 році, у вагітних з варикозною хворобою нижніх кінцівок у 53,7 \% відмічається прогресування захворювання [23].

Однією із причин виникнення варикозного розширення підшкірних вен нижніх кінцівок і зовнішніх статевих органів у вагітних $є$ гіперпрогестеронемія. Під час вагітності відбувається гор- мональна перебудова організму вагітної, що має значення також при проведенні знеболювання. Piвень прогестерону в сироватці крові збільшується порівняно з вихідним у 4,2-4,7 раза, а естрадіолу - в 5,7 раза [27]. За даними В. Д. Богачева (2002) [3, 4], А. В. Мурашко, 3. Х. Кулакова (2007) $[18,19]$, продукція прогестерону зростає в жіночому організмі у 250 разів, що приводить до затримки і накопичення рідини в тканинах. Збільшення маси циркулюючої крові на 20-30 \%, в свою чергу, створює додатковий тиск на стінки судин, особливо венозних, що сприяє підвищеному розширенню венозної стінки до 150 \% від норми. M. Lenckovic et al. (2009) [39] відмітили, що середня концентрація прогестерону у вагітних 3 варикозною хворобою значно вища, ніж без варикозного розширення підшкірних вен. Крім того, гіперпрогестеронемія знижує нервово-м'язову збудливість і чутливість нервового волокна, що зменшує до 30 \% потребу в місцевих анестетиках [14, 23, 25, 34].

Велике значення для вибору методу анестезії має знання анатомії та особливостей розвитку варикозного розширення підшкірних вен у вагітних жінок. Варикозному розширенню у 84,1 \% в ціло- 
му піддаються сафенові колатералі і притоки великої підшкірної вени. Добре розвинута м'язова оболонка магістральних підшкірних вен здатна періодично скорочуватися і протидіяти гідростатичній гравітації. Водночас їх бокові гілки мають тонкостінну будову, втрачають властивість довготривалої протидії і піддаються розширенню. Розширення бокових підшкірних гілок на стегні й гомілці частіше спостерігається в жінок із уродженою неповноцінністю клапанів чи їх невеликою кількістю [16, 41].

В Україні вагітним із різним ступенем варикозного розширення підшкірних вен нижніх кінцівок, з явищами хронічної венозної недостатності нижніх кінцівок основним лікуванням $€$ консервативна терапія, що передбачає носіння еластичного трикотажу (гольфів, панчіх чи колгот), в більшості 2 класу компресії, використання загальних, а за потребою й локальних венотоніків (з метою запобігання подальшому розширенню підшкірних вен та профілактики подальшого погіршення венозної гемодинаміки в нижніх кінцівках) [1, 2, 17]. Питання хірургічного втручання переносять до року після пологів [5, 26, 30, 34].

На думку Т. М. Каюкової (2006) [11], І. Б. Венцківської, Л. А. Жабіцької і співавт. (2008) [6], лікування вагітних з варикозним розширенням вен нижніх кінцівок і промежини повинно мати виключно індивідуальний підхід до кожного конкретного випадку, бути комплексним, що включає консервативні, фізіотерапевтичні й хірургічні методи та тісну співпрацю акушера і хірурга (флеболога). Слід зауважити, що хірургу необхідно мати спеціальну підготовку з діагностики, лікування і профілактики патології вен у вагітних з підбором необхідного комплексу лікувально-профілактичних заходів, що дозволять досягти добрих результатів лікування [25].

У певної групи вагітних має місце прогресування варикозної хвороби нижніх кінцівок, зовнішніх статевих органів і промежини попри консервативну терапію або неможливість ï̈ використання з тих чи інших причин.

Виникає необхідність ефективного, мінімального за об'ємом хірургічного втручання на поверхневій венозній системі нижніх кінцівок. Частота операційного втручання становить лише $6 \%$ від усієї кількості вагітних з варикозною хворобою нижніх кінцівок [23]. Лікарі-акушери переважно негативно ставляться до різних планових хірургічних втручань у жінок на фоні вагітності. Причина такого негативного ставлення $є$ зрозумілою через небезпеку завдати шкоди як матері, так і плоду, високий ризик післяопераційних ускладнень і проводиться у виключних випадках [19]. До вагітних пацієнток $з$ хірургічною патологією необхідно ставитись 3 увагою і повагою, а не $з$ ляком [34]. Г. Лейзерович (1999) [14], Charles et al. (2008) [34] та деякі інші автори відзначають, що принципи лікування хірургічної патології у вагітних такі ж, як у невагітних. Планові операційні втручання, на їх думку, краще проводити в II триместрі вагітності. В I триместрі вагітності не бажано, оскільки існує загроза самовільного аборту і тератогенної дії анестетиків. Відносно хірургічного лікування варикозного розширення вен нижніх кінцівок у вагітних маються лише окремі дані в працях Р. С. Колеснікової (1977) [13], К. В. Новікова (2001, 2009) [21, 22], В. В. Петрова (2011) [23], С. Г. Гаврилова і співавт. (2014) [7]. Ряд авторів - F. Curtis (1960) [36], К. Н. Залога (1965) [8], В. І. Кулаков і співавт. (1982) [12] почав використовувати хірургічні методи лікування варикозної хвороби нижніх кінцівок у вагітних. При цьому були сформовані показання до цього лікування: доцільно проводити лікування при наявності у вагітних великих варикозних вузлів явної клапанної недостатності і вираженого больового синдрому, порушення кровообігу в кінцівці при неефективній консервативній терапії; його можна проводити до 8 місяця вагітності. Виконували обмежені за об'ємом операційні втручання.

На думку Р. С. Колеснікової (1977) [13], показаннями до хірургічного лікування є: виражений ретроградний кровотік у підшкірні вени нижніх кінцівок, особливо при явних ознаках клапанної недостатності вказаних вен, субкомпенсованій стадії хронічної венозної недостатності, коли поряд із вираженим ретроградним кровотоком через остіальні клапани має місце недостатність клапанів комунікантних вен без порушення кровотоку по глибокій венозній системі.

У наш час хірургічне лікування варикозного розширення підшкірних вен нижніх кінцівок і зовнішніх статевих органів та промежини, особливо у вагітних, стає все менш агресивним. Стандартні методи операційного втручання при варикозній хворобі в цій групі хворих поступаються місцем хірургії “по карті”. “Карта” варикозних вен створюється на основі даних УЗД-ангіосканування з відображенням на схемі зон патологічних рефлюксів у венозній системі нижніх кінцівок і промежини [41]. У роботах В. В. Петрова (2011) [23], К. В. Новікова $(2001,2009)$ [21, 22] піднімається питання і про радикальне лікування певних форм варикозної хвороби у вагітних, що стало можливим завдяки УЗД-ангіоскануванню вен нижніх кінцівок. Виявляли під час обстеження зону патологічного рефлюксу крові та уражений сегмент 
підшкірних вен. Необхідно своєчасно усунути хірургічним шляхом зону патологічного рефлюксу крові, і патологічно змінений сегмент вени затримає чи зупинить процес варикозного переродження з позитивним результатом у 87 \% прооперованих вагітних [21, 22, 23].

Р. С. Колеснікова (1977) [13] вважає цілком достатньою при операційному втручанні, 3 причини варикозної хвороби нижніх кінцівок у вагітних, місцевої анестезії за допомогою повзучого інфільтрату за А. В. Вишневським. Анестезія за А. В. Вишневським дає повне знеболювання не тільки під час операції, але й впродовж декількох годин після операції. Інфільтраційна анестезія полегшує виділення варикозних вузлів, сприяє більш рельєфному виділенню розташування комунікантних вен. Операція під місцевим знеболюванням вимагає дуже уважного, дбайливого ставлення до тканин. Вона не сумісна з грубою технікою виконання. Тому всі маніпуляції (підтягування судин, розширення країв рани та ін.) необхідно виконувати ніжно і по можливості плавно.

Класична анестезія методом інфільтрації за А. В. Вишневським все частіше замінюється тумесцентною технікою (технікою “набухання”), запропонованою Дж. Кляйном (1990). Місцева анестезія методом “набухання” (тумесцентна техніка) сприяла революції у флебології. Розчин для анестезії дуже сильно розводиться розчином Рінгера. Він вводиться у великій кількості, щоб створився ефект розбухання тканин: для проведення втручання зазвичай використовується до 200 мл розчину анестетика. Алергія на речовину для анестезії виникає в дуже рідких випадках.

Цей метод має численні переваги: ін'єкції майже безболісні, відсутність токсичності навіть при виконанні двобічної флебектомії, дисекція венозного шляху при ін'єкції за ходом вени, компресія навколишніх тканин, яка знижує кровоточивість і запобігає утворенню гематом, довготривалий аналгезивний ефект.

Метод має незначні недоліки: зволожене операційне поле, ексудація з післяопераційних ран, час, затрачений на проведення інфільтрації.

Використовують місцеву інфільтраційну анестезію, в тому числі й тумесцентну, Ю. Л. Шевченко і співавт. (2005) при операційному втручанні на розширених підшкірних венах нижніх кінцівок. Проте додавання розчину адреналіну, на думку авторів, може викликати негативні реакції зі сторони серцево-судинної системи, через те автори його не використовують [28].

К. В. Новіков і співавт. (2001, 2009) [21, 22], В. В. Петров (2011) [23] також використовують місцеву анестезію при виконанні сегментарних венектомій у вагітних.

Ми прагнемо зробити все можливе для комфортного виношування вагітності, запобігти або зменшити ступінь змін у венозній стінці при варикозному розширенні підшкірних вен, зовнішніх статевих органів та промежини, активно запобігти тромботичним, тромбоемболічним та геморагічним ускладненням при варикозній хворобі нижніх кінцівок, зовнішніх статевих органів під час вагітності, пологів і в післяпологовому періоді.

Мета роботи: розробити сумісно 3 лікарями-акушерами і судинними хірургами показання до тумесцентної анестезії як різновиду місцевої анестезії для безпечного хірургічного втручання, щоб запобігти прогресуванню варикозної хвороби нижніх кінцівок, статевих губ і промежини у вагітних із мінімальним впливом на перебіг вагітності, розвиток плода і для коректного виношування вагітності.

Матеріали і методи. На базі КЗ “Обласний перинатальний центр” Рівненської обласної ради за період з лютого 2013 р. до березня 2016 р. спостерігали 562 вагітних із варикозним розширенням підшкірних вен нижніх кінцівок, зовнішніх статевих органів і промежини, що складало 9,8 \% від усіх вагітних, які народжували в центрі, і 5,3 \% від числа хворих, які лікувались у закладі. Із них у 256 (45,5 \%) вагітних відмічено виражене прогресування варикозного розширення підшкірних вен нижніх кінцівок, на одній із кінцівок - у 196 (76,5 \%) пацієнток, а на обох - у 60 (24,5 \%); зовнішніх статевих органів і промежини - 37 (6,6 \%), в поєднанні варикозного розширення підшкірних вен нижніх кінцівок та зовнішніх статевих органів і промежини - у 79 вагітних (14,05 \%). Серед пацієнток, що вперше народжують, прогресуюче варикозне розширення підшкірних вен відмічено у 96 (37,5 \%), при повторних пологах - у 170 (63,5 \%).

Для дослідження підшкірних і глибоких вен нижніх кінцівок при прогресуючому варикозному розширенні підшкірних вен нижніх кінцівок використовували апарат УЗД “Landwind Mirror 2" 3 лінійним датчиком L5-10|40Е в В-режимі зі спектральною доплерографією, виробництва КНР. Використання дуплексного сканування у вагітних із варикозною хворобою нижніх кінцівок дозволило повноцінно оцінити як анатомічні особливості будови венозної системи, так і об'єктивізувати порушення флебогемодинаміки з їі топічною характеристикою, що сприяло виробленню раціональної тактики лікування пацієнток, яка базувалась на 
патогенетичних механізмах розвитку варикозного розширення підшкірних вен з індивідуальним підходом до кожної пацієнтки. Ультразвукове картографування ділянок патологічних рефлюксів $€$ важливим компонентом в оцінці стану венозної системи нижніх кінцівок.

Основними проявами венозної недостатності нижніх кінцівок при прогресуючій варикозній хворобі нижніх кінцівок були: набряки м'яких тканин гомілки i/або стоп різного ступеня - у 256 (100\%) вагітних, тяжкість у нижніх кінцівках у 202 (79,1 \%) пацієнток, парестезії в ділянці гомілок і стоп (у вигляді відчуття тепла, повзання мурашок) - у 174 (67,5 \%) вагітних, судоми в м’язах гомілки і/або стопи - у 115 (45,1 \%) пацієнток, свербіння шкірних покривів гомілки - у 66 (25,8 \%) вагітних. Ці симптоми мали тенденцію до прогресування під час вагітності. Оцінку клінічних проявів захворювання проводили за 3-бальною шкалою (від 0 до 3) за Rutherford et al. (2000) [42]:

- біль у нижніх кінцівках у 2 бали відмічено у 196 (76,5 \%) вагітних, у 3 бали - у 60 (23,5 \%);

- варикозні вени нижніх кінцівок у 2 бали в 234 (91,4 \%) вагітних і в 3 бали - у 22 вагітних (8,6\%);

- венозні набряки в 1 бал - у 65 (25,4 \%) вагітних, у 2 бали - у 178 (69,5 \%), і в 3 бали - у 13 (5,1\%) вагітних.

Після з’ясування причин прогресування варикозної хвороби нижніх кінцівок, зовнішніх статевих органів і промежини у вагітних лікар-акушер i судинний хірург приймали колегіальне рішення про ефективний метод подальшого лікування даної патології, яке доводили до відома вагітної. Остаточне рішення про тактику лікування - хірургічну чи продовження консервативної терапії - приймала сама вагітна.

Із 256 вагітних з прогресуючим розширенням підшкірних вен нижніх кінцівок, зовнішніх статевих органів і промежини на операційне втручання дали згоду 114 (44,5 \%) вагітних, а з усіх вагітних із варикозним розширенням підшкірних вен, яких спостерігали в перинатальному центрі, кількість оперованих становила 20,24 \%. Хірургічне лікування проведено 76 (66,6 \%) пацієнткам із прогресуючою варикозною хворобою нижніх кінцівок і 7 (6,14 \%) вагітним - із прогресуючим розширенням підшкірних вен зовнішніх статевих губ та промежини. Крім того, 30 (26,3 \%) вагітним - iз поєднанням прогресуючого розширення підшкірних вен нижніх кінцівок і зовнішніх статевих органів та промежини.

Виконано 154 операційних втручання: 118 (76,3 \%) втручань в II триместрі вагітності і в III триместрі - 36 (23,7 \%) втручань. Всі операційні втручання виконували в плановому порядку. Використовували для знеболювання в 90,8 \% вагітних місцеву анестезію, різновид її - тумесцентну анестезію за Дж. Кляйном, з модифікованим нами розчином анестетика, що придатний для виконання операційних втручань під час вагітності. Виключали з розчину адреналін, який негативно впливає на серцево-судинну систему як вагітної, так і плода. Жодних алергічних проявів на введення низькоконцентрованого розчину анестетика (0,1 \% розчин новокаїну) в оперованих вагітних і плода не спостерігали. Змін гемодинаміки у вагітних і плода під час проведення знеболювання і операційного втручання не відмічено. Для запобігання розвитку синдрому нижньої порожнистої вени або аортокавального синдрому у вагітних під час операційного втручання укладали вагітну на операційний стіл на лівий бік під кутом $30^{\circ}$. Оперували пацієнток з варикозно розширеними підшкірними венами нижніх кінцівок і зовнішніх статевих органів та промежини без порушень венозного кровотоку по глибоких венах нижніх кінцівок та клубових вен класу С2 - 98 (85,9 \%) вагітних, і 26 (14,1 \%) вагітних - класу С3 (за гавайською класифікацією СЕАР).

Проводили клінічне та лабораторне обстеження вагітної, а при потребі - відповідну підготовку вагітної і плода. На операційне втручання отримували згоду як від вагітної, так і від акушера.

Показання до здійснення операційного втручання:

1. Неефективна, повноцінна, відповідно до протоколів, консервативна терапія, яку проводили вагітним впродовж 2-3 місяців і яка проявлялась:

- вираженим наростаючим болем за ходом варикозно розширених вен нижніх кінцівок;

- вираженим, прогресуючим розширеним внутрішньошкірним варикозом на гомілках, що супроводжувався болем і косметичним дефектом;

- вираженим прогресуючим варикозом зовнішніх статевих органів, що супроводжувався болем під час сидіння, фізвідправленнях і ніс загрозу кровотечі при родорозрішенні природними шляхами;

- нічними судомами у м'язах нижніх кінцівок;

- значним варикозним розширенням підшкірних вен нижніх кінцівок та наростанням набряку м’яких тканин гомілок і стоп.

2. Питання косметичного дефекту нижніх кінцівок і зовнішніх статевих губ через внутрішньошкірний варикоз, варикозне розширення підшкірних вен.

3. Активна профілактика тромботичних і тромбоемболічних ускладнень варикозної хвороби ниж- 


\section{З ДОСВІДУ РОБОТИ}

ніх кінцівок при одночасному проведенні родорозрішення через кесаревий розтин.

Основні причини варикозного розширення підшкірних вен нижніх кінцівок і статевих губ оперованих нами вагітних за даними УЗД-сонографії:

- патологічний рефлюкс крові через крос у систему великої підшкірної вени і її приустевих гілок - 54 (47,4 \%);

- патологічний рефлюкс через підшкірно-підколінне співустя - 7 (6,14 \%);

- патологічний рефлюкс через підшкірно-стегнове і підшкірно-підколінне співустя - 12 (10,5 \%);

- патологічний рефлюкс через підшкірно-стегнове і підшкірно-підколінне співустя в поєднанні через перфорантні вени гомілки і стегна - 28 (24,56\%).

Усім 114 (100 \%) вагітним операційні втручання виконували в плановому порядку:

- у II триместрі - 78 (59,6 \%) вагітним;

- у III триместрі - 36 (31,5 \%) пацієнткам.

3’ясували наявність і ступінь прояву синдрому нижньої порожнистої вени i/або аортокавального синдрому у вагітних від положення вагітної в ліжку, що дуже важливо для вибору положення вагітної на операційному столі. Крім того, визначили час комфортного перебування вагітної в такому положенні.

Тому 76 (66,7 \%) пацієнток змушені були перебувати на лівому боці на операційному столі під кутом $30^{\circ}$, або нахиляли деку операційного столу на $30^{\circ}$ вліво, що дозволяло різко зменшити ступінь проявів синдрому нижньої порожнистої вени.

У більшості, 97 (85,08 \%) вагітним, виконували операційне втручання на венах як самостійне операційне втручання, і лишень 7 (6,14 \%) - у поєднанні із кесаревим розтином.

При операційному втручанні тільки на венозній системі нижніх кінцівок використовували у 97 (85,08 \%) вагітних місцеву інфільтраційну анестезію, різновид ії - тумесцентну анестезію за Дж. Кляйном (1990) [40] з модифікованим нами розчином анестетика і методикою проведення iї у вагітних.

Виконано 154 операційних втручання 114 вагітним: 93 операційних втручання на одній нижній кінцівці і 61 операційне втручання - на двох нижніх кінцівках (48 вагітним - на двох нижніх кінцівках одночасно, а 12 вагітним - почергово через день).

Варіанти операційних втручань:

- ізольована приустева перев’язка великої підшкірної вени та ії гілок - 68 (44,15 \%);

- ізольована перев’язка малої підшкірної вени та її гілок - 15 (9,7\%);
- одночасна приустева перев'язка малої та великої підшкірних вен і їх гілок - 25 (16,23 \%);

- одночасна приустева перев’язка великої підшкірної вени i/або малої підшкірної вени та їх гілок у поєднанні з перев'язкою перфорантних вен стегна і/або гомілки - 14 (9,09 \%);

- перев’язка приустева великої і/або малої підшкірних вен та їх приток i/або перфорантних вен гомілки з міні-флебектомією за Мюллером (1996) [38] - 32 (20,77\%).

Результати досліджень та їх обговорення. Оцінку результатів хірургічного лікування проводили на другий день і через 2 тижні після операції. Суб’єктивну оцінку результатів лікування здійснювали самі вагітні за такими критеріями: біль за ходом вен, судоми в м’язах нижніх кінцівок, стан кінцівки (ступінь проявів варикозного розширення підшкірних вен нижніх кінцівок, набряк м'яких тканин ступні і низу гомілки). Розроблений нами комплекс заходів дозволив у 100 \% вагітних отримати позитивний результат хірургічного лікування пацієнток із прогресуючою варикозною хворобою нижніх кінцівок і вберегти їх від ускладнень.

Крім того, оцінку результатів хірургічного лікування варикозного розширення підшкірних вен нижніх кінцівок і зовнішніх статевих органів та промежини намагались об’єктивізувати.

Для цього використовували 3-бальну шкалу (від 0 до 3) за Rutherford і співавт. (2000) [42]:

- біль в 0 балів - 73 (96,1 \%) оперованих, 1 бал $-3(3,9 \%)$;

- варикозні вени в 1 бал - 76 (100%) оперованих;

- венозні набряки в 0 балів - у 56 (73,6\%) вагітних, в 1 бал у 20 (26,4 \%) вагітних.

Через 2 тижні після операції всім 114 прооперованим вагітним виконували контрольну УЗДсонофлебографію оперованих ділянок. Констатовано, що підшкірно-стегнове і/або підшкірно-підколінне співустя, комунікантні вени гомілки i/або стегна не функціонують (перев’язані). Залишені підшкірні вени стегна i/або гомілки помірного наповнення, в підшкірній клітковині гомілок і стоп відсутні або зовсім незначні ознаки набряку м’яких тканин.

Перев’язку великої підшкірної вени та її гілок виконували з індивідуального доступу для кожної вагітної із мінімального розрізу по довжині (до 2 см) у проекції кросу, що стало можливим завдяки УЗД-картографуванню даної ділянки і значно знизило труднощі при виділенні кросу, зменшило травматизм м'яких тканин.

У 114 (100 \%) оперованих вагітних післяопераційні рани загоїлися первинним натягом. Викорис- 
товували для зашивання внутрішньодермальні вузлові шви, які не знімаються. Такий тип швів різко зменшує больові відчуття в післяопераційній рані.

В усіх оперованих нами вагітних із скомпрометованими венами з метою зменшення больових відчуттів у рані їх виділяли на мінімальному протязі: до 1,5-2 см стовбур великої підшкірної вени в ділянці кросу, а декомпенсовані комунікантні вени виділяли надфасціально на протязі до 1 см. Виконували тільки їх перев'язку синтетичними нитками, що не розсмоктуються: стовбур 2-3 лігатурами, а гілки - одинарною лігатурою. Ми виходили з того, що в стінках периферичних вен $є$ больові сенсорні волокна [29, 31].

Операційні втручання виконували без премедикації. Проводили психологічну підготовку вагітних із метою зняття у них напруження, яка включає в себе роз’яснення суті місцевої анестезії та попереднє пояснення змісту майбутніх відчуттів. Це так звана “розмовна анестезія”, яка тривала і під час операції. Особи жіночої статті під час вагітності мають виражену гіперпрогестеронемію (кількість прогестерону в організмі вагітної жінки збільшується 4,3-4,5 раза), що асоціюється з аналгезією та анестезією і приводить до зменшення концентрації та дози анестетика до 40 \%. Крім того, вони вміють завчасно себе підготувати до болю “з передбаченням болю”, наче “зануритись” у больові відчуття з головою [15, 31].

При переведенні вагітної в операційний зал катетеризується одна з периферичних вен з інфузією фізрозчину рідкою краплею. Присутній при виконанні операції лікар-анестезіолог веде спостереження за вагітною. При потребі запрошують акушерку, яка спостерігає за станом плода.

Акушерська практика ставить високі вимоги до місцевих анестетиків через те, що у вагітних знижені адаптивні можливості фізіологічних систем організму. Місцеві анестетики для використання в даній групі пацієнток мають бути із мінімальним кардіотоксичним впливом, 3 контрольованим впливом на гемодинаміку, із високою місцевою анестезувальною активністю та достатньою тривалістю дії. I, не менш головне, простотою виконання анестезії, і в жодному випадку кровопостачання плода не має порушуватись [34 ].

Тумесцентна анестезія за Дж. Кляйном [40], яку ми використовували, відповідала вищеперерахованим вимогам, дозволила виконати об'єм операційного втручання, що був запланований, без погіршення стану матері й плода 3 мінімальною концентрацією анестетика і його кількістю.

За суб’ єктивною оцінкою вагітних, інтенсивністю болю в ділянці операційних доступів відмічено таке: найбільш чутлива ділянка - це перехід великої підшкірної вени в стегнову, що потребувало більшої

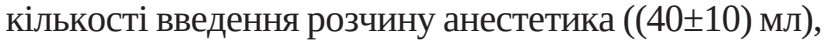
шляхом помірного нагнітання в простір між поверхневою і глибокою фасціями. Менш чутливі ділянки - в нижній третині стегна і гомілки. Кількість вико-

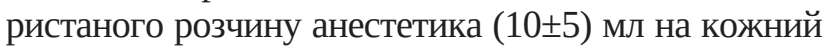
доступ в цих ділянках. Загальна кількість використаного розчину анестетика $(80 \pm 10)$ мл. Алергічних проявів на введення анестетика під час операції і в післяопераційному періоді не відмічено. Анестезувальний ефект в ділянці операційних ран після операції утримувався протягом 10-12 год. Потребували введення анальгетиків (одноразово) в післяопераційному періоді 12 (10,5 \%) вагітних.

Передбачення можливості розвитку синдрому нижньої порожнистої вени або аортокавального синдрому у вагітних, особливо в III триместрі, зменшення його впливу на вагітну і плід у 87 \% вагітних вирішувалось укладанням їх на операційному столі на лівий бік під кутом до $30^{\circ}$, або на-

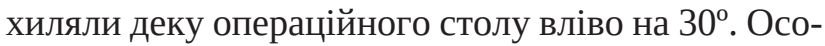
бливу увагу звертали й акцентували матері на підсилення активності плода. Раптове підсилення активності плода, яке відчуває вагітна, можна розглядати як ознаку значних гемодинамічних зрушень, зумовлених аортокавальним синдромом [9].

Операційне втручання намагались провести вагітним у період часового комфорту, індивідуально для кожної вагітної. Середня тривалість

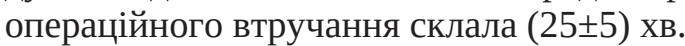

Усі прооперовані вагітні в II триместрі перебували на стаціонарному лікуванні до 2 днів і виписувались під спостереження лікаря-акушера за місцем проживання після переконання в стабільності стану вагітної і плода, а прооперовані вагітні в III триместрі перебували до пологів у стаціонарі. Проте деякі автори, серед яких К. В. Новіков і співавт. (2001, 2009) [21, 22], рекомендують ведення раннього післяопераційного періоду в денному стаціонарі вдома. У прооперованих вагітних погіршення перебігу вагітності, пологів не відмічено. Плід не потерпав.

У післяопераційному періоді вагітним одразу рекомендували виконувати дозовані фізичні навантаження (ходьба), щільне бинтування ступні, гомілки в межах компресії класу 2. Систематичне бинтування або носіння еластичного компресійного трикотажу запобігає прогресуванню хвороби і прискорює периферичний кровообіг в оперованій кінцівці до 5 разів [16].

Дезагреганти, антикоагулянти, системні й локальні венотоніки призначали виключно за індивідуальними показаннями. 
Висновки. 1. Тісна співпраця лікаря-акушера і судинного хірурга в спеціалізованому акушерському закладі $є$ визначальною у виборі методу знеболювання, якщо віддають перевагу місцевій анестезії (ії різновиду - тумесцентній анестезії).

2. Визначалися з тактикою лікування прогресуючої варикозної хвороби нижніх кінцівок у вагітних, віддаючи перевагу хірургічному лікуванню. Знання особливостей перебігу вагітності, змін в анатомії, гемодинаміці у венозній системі нижніх кінцівок під час вагітності сприяло у виборі адекватного хірургічного втручання в оптимальні терміни вагітності висококваліфікованим флеболо-

\section{СПИСОК ЛІТЕРАТУРИ}

1. Артимук Н. В. Варикозное расширение вен органов малого таза / Н. В. Артимук // Рос. вест. акушер-гинеколога. 2007. - № 6. - C. 74-77.

2. Комплексна терапія гестаційної варикозної хвороби / В. О. Бенюк, В. І. Медведь, С. Д. Коваль, В. В. Курочка // Здоровье женщины. - 2011. - № 6 (62). - С. 12-14.

3. Богачов В. Ю. Варикозная болезнь во время и после беременности / В. Ю. Богачов // Гинекология. - 2006. - № 8 (5). - C. $24-28$.

4. Богачев В. Д. Гормональноиндуцированная флебопатия. Новая проблема современной флебологии / В. Д. Богачев // Ангиология и сосудистая хирургия. - 2002. - № 3. - С. 50-57. 5. Буданов П. В. Современные возможности профилактики лечения венозной недостаточности во время беременности / П. В. Буданов, П. А. Авланова // Гинекология. - 2009. - № 6. - C. $10-14$

6. Венцківська І. Б. Вінітан Форте при варикозній хворобі у вагітних / І. Б. Венцківська, Л. А. Жабіцька, К. О. Венцківський // Медицинские аспекты здоровья женщины. - 2008. 2 (11) март. - С. 10-12.

7. Вульварный варикоз: диагностика, лечение, профилактика / Гаврилов С. Г., Москаленко Е. П., Каралкин А. В. [и др.] // Анн. хирургии. - 2014. - № 4. -С. 14-16.

8. Залога К. Н. Варикозное расширение вен при беременности и его лечение / К. Н. Залога // Хирургия. - 1965. - № 9. - С. 38-41.

9. Зильбер А. П. Акушерство глазами анестезиолога / А. П. Зильбер, Е. М. Шифман. - Петрозаводск, 1997. - 396 с. 10. Кайдорин А. Г. Пути оптимизации диагностики хирургического лечения неосложненной варикозной болезни : автореф. дисс. на соискание учёной степени доктора мед. наук / А. Г. Кайдорин. - Новосибирск, 1997. - 48 с.

11. Каюкова Т. М. Хронічна венозна недостатність нижніх кінцівок у вагітних: сучасний погляд на проблему / Т. М. Каюкова // Жіночий лікар. - 2006. - № 5. - С. 15-16.

12. Кулаков В. И. Острый тромбофлебит нижних конечностей в акушерстве / В. И. Кулаков, В. В. Черная, В. П. Балуда. - М. : Медицина,1982. - 208 с.

13. Колесникова Р. С. Лечение заболеваний вен у женщин (в связи с беременностью и родами) / Р. С. Колесникова. - М. : Медицина, 1977. - 183 с.

14. Лейзерович Г. Хирургические и гинекологические болезни у беременных / Г. Лейзерович // Акушерство : справочник Калифорнийского универсистета. - М., 1999. - Гл.15. - С. 318-347. 15. Лесной И. И. Особенности восприятия боли у женщин / И. И. Лесной, Л. В. Климчук, И. Н. Лесная // Медицинские гом і дозволило отримати (за суб'єктивною оцінкою вагітних) 100 \% позитивний результат.

Перспективи подальших досліджень. Перспективним $є$ подальше розширення показань до операційного втручання у вагітних із прогресуючим розширенням підшкірних вен нижніх кінцівок, зовнішніх статевих органів для коректного виношування вагітності, запобігання тромбоемболічним і тромбофлебітичним ускладненням як до пологів, так і після них, геморагічним ускладненням при пологах через природні родові шляхи.

аспекты здоровья женщины. - 2010. - 8 (37) ноябрь. - С. 68-71.

16. Мамамтаврашвили Д. Г. Спорные вопросы хирургического лечения окклюзирующих заболеваний вен нижних конечностей / Д. Г. Мамамтаврашвили. - 1967. - № 9. - С. 93-95.

17. Медведь В. И. Венозные осложнения у беременных / В. И. Медведь, В. А. Бенюк, С. Д. Коваль // Медицинские аспекты здоровья женщины. - 2010. - № 7 (35). - С. 29-33. 18. Хроническая венозная недостаточность и беременность / А. В. Мурашко, 3. Х. Кумыкова // Гинекология. - 2007. - Т. 9, № 1. - C. 98-102.

19. Мурашко А. В. Медикаментозная терапия хронической венозной недостаточности во время беременности / А. В. Мурашко // Акушерство и гинекология. - 2002. - № 6. - С. 25-28. 20. Николаенкова В. А. К вопросу о патогенезе варикозной болезни вен нижних конечностей / В. А. Николаенкова // Материалы науч. конф., посвященной 50-летию ин-та : труды Смолен. мед. ин-та. - 1970. - Т. 29. - С. 161-163.

21. Новиков К. В. Хирургическое лечение варикозной болезни вен нижних конечностей у беременных / К. В. Новиков // Амбулаторная хирургия. - 2001. - № 2 (2). - С. 37-38.

22. Новиков К. В. Хирургическое лечение варикозной болезни у беременных / К. В. Новиков, В. В. Воробйов, В. Г. Абашин // Амбулаторная хирургия. - 2009. - № 3-4 (35-36) ноябрь. - С. 40-41.

23. Петров В. В. Сегментарная флебектомия у беременных с прогрессирующей варикозной болезнью вен нижних конечностей : автореф. дисс. на соискание научной степени канд. мед. наук / В. В. Петров. - СПб., 2011.

24. Романенко Т. Г. Хроническая венозная недостаточность во время беременности. Лиотон 1000 гель: опыт лечебно-профилактического применения / Т. Г. Романенко // Здоровье женщины. - 2011. - № 9 (65). - С. 83-86.

25. Сабельников В. В. Варикозная болезнь нижних конечностей. Современный взгляд на проблему / В. В. Сабельников, Е. К. Шулепова // Мир медицины. - 2001. - № 3-4. - С. 3-5. 26. Цыбоева Г. И. Выбор метода лечения варикозной болезни и ее осложнений у беременных, родильниц : дисс. ... канд. мед. наук / Г. И. Цыбоева. - Душанбе, 2005. - С. 108.

27. Шарав Цэрэнсабуу. Варикозная болезнь вен нижних конечностей при беременности (состояние фетоплацентарной системы) : автореф. дисс. на соискание научной степени канд. мед. наук / Шарав Цэрэнсабуу. - Иркутск, 2004.

28. Шевченко Ю. Л. Основы клинической флебологии / под ред. Ю. Л. Шевченко, Ю. М. Стойко, М. И. Лыткина. - М. : ОАО “Издательство “Медицина”. - 2005. - 312 с. 


\section{З ДОСВІДУ РОБОТИ}

29. Шекоян А. О. Венозная боль: патофизиология и принципы лечения / А. О. Шекоян, В. Ю. Богачев // Флеболифология. 2010. - № 36. - C. 2-5.

30. Шехтман М. М. Руководство по экстрагенитальной патологии у беременных / М. М. Шехтман. - М. : Триада-Х, 2003. -816 c.

31. Arnold J. O. Pain evoked by polymodal stimulation of hand veins humans / J. O. Arnold, W. Klement // J. Physiol. - 1991. P. 440-467.

32. Vulvar varices an uncommon entitu in surgical pathologu / D. Bell, P. B. Rane, S. Liang [et al.] // Int. J. Gynecol. Pathol. 2007. - Vol. 26(1). - P. 99-101.

33. Danilenko-Dixon D. R. Risk factors for deep vein thrombosis and pulmonary embolism during pregnancy or post partum a population based case -control stady / D. R. Danilenko-Dixon, J. A. Heit, M. D. Silverstein // Am. J. Obstet. Gynecol. 2001. Vol.184, No. 2. - P. 104-110.

34. Delaney A. G. Anestesia in the pregnant woman / A. G. Delaney // Clin. Obsstet. Gynecology. - 1983. - P. 246-248.

35. Charles P. Анестезия у беременных с не акушерской патологией / P. Charles, M. O. Gibbs // Медицина неотложных со- стояний. - 2008. - Vol. 4(17). - C. 21-23.

36. Curtis A. The surgery of varicose veins in pregnancy fnd its resulths / A. Curtis // Proc. Roy. Soc. Med. - 1960. - Vol. 53. P. 840-841.

37. Fassiadiadis N. Tretment for pelvic congestion syndrome causing pelvic and vulvar varices / N. Fassiadiadis // Int. Angiol. - 2006. - Vol. 25(1). - P. 1-3.

38. Muller R. Mise fu point sur la phlebectomie ambulatoire selon muller / R. Muller // Phlebologie. -1996. - № 49. - P. 335-344.

39. Effecti of progesterone and pregnancy on the development of varicose veins / M. Lenkovic, L. Cabrign, F. Giuber [et al.] // Acta. Dermatovenerol. Crout. - 2009. - Vol. 17, No. 4. - P. 263267.

40. Klen J. A. Tumescent technigue for regional anesthesia permits lidocaine doses of $35 \mathrm{mg} / \mathrm{kg}$ for liposuction / J. A. Klen // J. Dermatol. Suegr. Oncol. - 1990. - No. 16. - P. 248-263.

41. Ramelet A. A. Les varices et telangiectasies Masson / A. A. Ramelet, P. Kern, M. Perrin. - Paris. - 2003.

42. Venous severitu scoring an adjunct to venous outcome assessment / R. B. Rutherford, F. T. Jr. Padberg, J. Comerota [et al.] // J. Vasc. Surg. - 2000. - Vol. 31. - P. 130.

Отримано 28.07.16 